\title{
Lessons Learned from an Emergency Bridge Replacement Project
}

\author{
Yong Bai, P.E., M.ASCE ${ }^{1}$; William R. Burkett, P.E. ${ }^{2}$; and Phillip T. Nash, P.E. ${ }^{3}$
}

\begin{abstract}
The terrorist attack on September 11, 2001, and subsequent potential threats to U.S. transportation systems have presented an urgent need to develop emergency response plans to quickly react to the possible consequences of extreme events. Extreme events include terrorist attack as well as man-made and natural disasters such as explosions, fires, floods, and earthquakes. The objective of this research was to identify strategies and technologies to quickly restore the use of highway bridges, a critical component of the nation's transportation network, in case they are damaged or destroyed by extreme events. One of the tasks associated with this research was to conduct case studies of previous bridge replacements following extreme events. By studying these cases, the research team sought to identify and expand on lessons learned, address which actions did and did not work well given the circumstances of the incident, and incorporate lessons into the emergency response plan for highway bridges. This paper presents the findings from one of the case studies, the I-40 Webbers Falls Bridge in Oklahoma.
\end{abstract}

DOI: 10.1061/(ASCE)0733-9364(2006)132:4(338)

CE Database subject headings: Bridge construction; Bridges, highway; Terrorism; Damage assessments; Oklahoma; Replacement.

\section{Introduction}

The terrorist attacks on September 11, 2001, and subsequent potential threats to U.S. transportation systems have presented an urgent need for government agencies such as state Departments of Transportation (DOTs) to develop emergency response plans to quickly react to the possible consequences of an extreme event. Highway bridges, as a critical component of the nation's transportation network, have been brought to closer attention by government agencies. A pooled-fund research project, led by the Texas Department of Transportation and titled "Rapid Bridge Replacement Techniques," was conducted beginning in March 2002. Other entities participating in the project were the state DOTs of Georgia, Illinois, Minnesota, Mississippi, New Jersey, New Mexico, Ohio, and South Carolina.

One of the tasks associated with the research project was to conduct several case studies of previous bridge replacements following extreme events. These events included explosion and fire caused by roadway vehicle impact, waterway vessel collision, flood damage, and earthquake damage. The research team reviewed 26 bridge incident cases in the United States and overseas

\footnotetext{
${ }^{1}$ Assistant Professor, Dept. of Civil, Environmental, and Architectural Engineering, Univ. of Kansas, 1530 W. 15th St., 2150 Learned Hall, Lawrence, KS 66045. E-mail: ybai@ku.edu

${ }^{2}$ Associate Professor, Dept. of Engineering Technology and Civil Engineering, Texas Tech Univ., Lubbock, TX 79409. E-mail: Randy.Burkett@coe.ttu.edu

${ }^{3}$ Senior Researcher, Dept. of Civil Engineering, Texas Tech Univ., Lubbock, TX 79409.

Note. Discussion open until September 1, 2006. Separate discussions must be submitted for individual papers. To extend the closing date by one month, a written request must be filed with the ASCE Managing Editor. The manuscript for this paper was submitted for review and possible publication on May 10, 2004; approved on June 15, 2005. This paper is part of the Journal of Construction Engineering and Management, Vol. 132, No. 4, April 1, 2006. CASCE, ISSN 0733-9364/2006/4$338-344 / \$ 25.00$.
}

and identified three cases on which to perform detailed studies. They were the I-95 Chester Creek Bridge in Pennsylvania in 1998, the Governor Thomas E. Dewey Thruway Bridge in New York in 1997, and the I-40 Webbers Falls Bridge in Oklahoma in 2002. The reasons for which these bridges were chosen were that all were critical components in the nation's interstate system and the incidents had significant impacts on the traveling public and surrounding communities.

\section{Research Objective}

The objective of this research was to identify strategies and technologies to quickly restore highway bridges, a critical component of the nation's transportation network, to their use in case they are damaged or destroyed by extreme events. A case study methodology was utilized to accomplish this objective. By studying previous cases, the research team sought to identify and expand on lessons learned, address which actions did and did not work well given the circumstances of the incident, and incorporate these lessons into an emergency response plan for highway bridges.

\section{Case Study Methodology}

Case studies were conducted using a three-step approach. First, the research team reviewed the literature related to the cases, including newspaper articles, conference and journal papers, technical reports, and Web sites. Second, the research team interviewed the people who were involved in the case via telephone. These people came from state DOTs, design firms, contractors, and material suppliers. In these telephone interviews, researchers asked them a series of questions regarding their roles and knowledge about the case. After the first two steps, the research team had an initial understanding of each case, and unanswered questions were clearly outlined. The third step was to conduct a survey comprising the previously unanswered questions and additional 


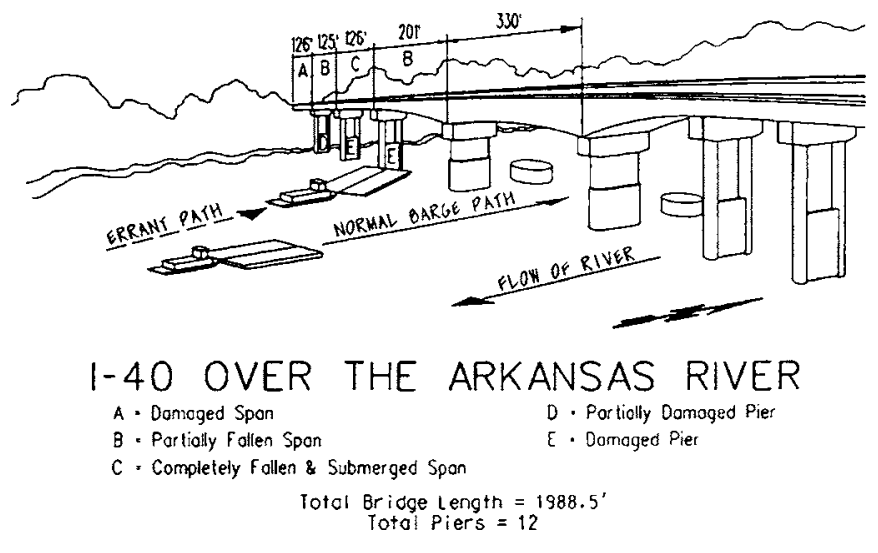

Fig. 1. I-40 bridge incident sketch

needed information related to each case. The survey questionnaire consisted of five aspects, including contracting method, engineering, construction, state DOT support, and material supplier and vendor support.

There were several reasons for choosing the survey method to acquire knowledge. First, the survey was a relatively easy way to solicit answers to the same questions from several people. Second, the survey questionnaire provided, in general, a very clear statement of the problems. Third, the survey gave people more time to respond to the questions as compared to personal interviews. Fourth, the survey results were easy to compare and analyze. At the end of each case study, a report was generated including the lessons learned. This paper presents the I-40 Webbers Falls Bridge case in Oklahoma and lessons learned from this incident.

\section{I-40 Webbers Falls Bridge Incident}

On the Memorial Day weekend of May 26, 2002, the towboat Robert Y. Love, pushing two empty barges owned by the Magnolia Marine Transport Company of Vicksburg, Mississippi, was moving upstream on the Arkansas River when it hit the I-40 Webbers Falls Bridge around 7:47 am. The incident caused a portion of the bridge, which is part of McClellan-Kerr Arkansas River Navigation System (waterway), to fall into the river. Drivers of 11 vehicles were unaware of the bridge collapse and plunged $19 \mathrm{~m}$ $(62 \mathrm{ft})$ into the river. A total of 14 people died in the incident. The Oklahoma Department of Transportation (ODOT) closed I-40 near the bridge and the Navigation System. Interstate 40, one of the nation's three major east-west interstate highways, carries about 20,000 vehicles each day, transporting people, goods, and materials coast to coast (Stidger 2002).

\section{Damage Assessment}

The $20 \mathrm{~m}(64 \mathrm{ft})$ wide, $606 \mathrm{~m}(1988 \mathrm{ft})$ long, four-lane bridge was built in 1967 over the Arkansas River near Webbers Falls, Oklahoma ("Oklahoma" 2002). The original structure was a continuous haunched steel girder bridge with a 61-101-61 m (201-330 $200 \mathrm{ft}$ ) main span combined with steel girder approach spans and a reinforced concrete deck. The steel girders were supported by 12 concrete piers. Fig. 1 shows the normal barge path and the errant barge path that resulted in a collision with the bridge. The barge was about $91 \mathrm{~m}(300 \mathrm{ft})$ outside the regular navigation channel (main channel) when it rammed into the unprotected

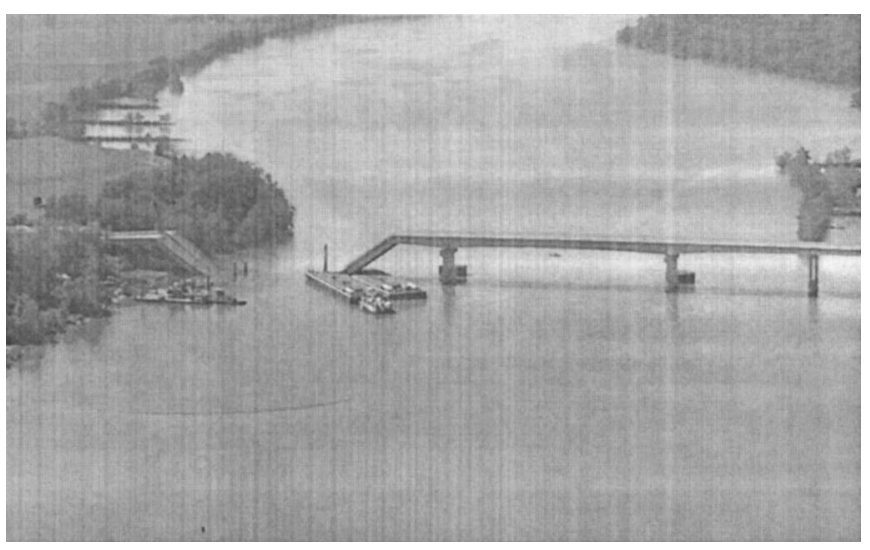

Fig. 2. Overview of damaged bridge

piers of the bridge, knocking down two piers (indicated as $\mathrm{E}$ piers) and partially damaging another (indicated as the D pier). Four spans totaling approximately $152 \mathrm{~m}(500 \mathrm{ft})$ were also damaged. Span 1 [38 m (126 ft), shown as damage type A] was damaged, but did not fall. Span $2[38 \mathrm{~m}(125 \mathrm{ft})$, shown as damage type B] and Span 4 [61 m (201 ft), shown as damage type B] partially fell into the river. Span $3[38 \mathrm{~m}(126 \mathrm{ft})$, shown as damage type C] completely collapsed into the river. Fig. 2 shows the damaged bridge.

\section{Detour Routes}

Shortly after the incident, ODOT established detour routes for the traveling public as shown in Fig. 3. Eastbound drivers were instructed to take exit 278 at Warner, go south on SH-2, turn east on SH-9, turn north on US-59, and rejoin I-40 near Sallisaw at exit 308. The eastbound detour was $92 \mathrm{~km}$ (57 mi) long (Greiner 2002). Westbound travelers were directed to take exit 291 at Gore, go north on SH-10, turn west on US-64, turn south on SH-100, and rejoin I-40 east of Muskogee Turnpike at exit 287. The westbound detour was $10 \mathrm{~km}$ (6 mi) long (Greiner 2002). In order to reduce the traffic volume on area highways, ODOT instructed long-distance travelers from northern Oklahoma, including Kansas, to go south on I-35, then east on US-412/Cimarron Turnpike to avoid area traffic congestion. Long-distance drivers from northeastern Oklahoma, Tulsa, and surrounding areas were directed to go east on US-412/Cherokee Turnpike, turn south on I-540, then turn east onto I-40 in Ft. Smith, Arkansas. Travelers coming into Oklahoma from Texas to access I-40 east of Warner, Oklahoma, were instructed to take I-30 from Texas into Arkansas, and then take I-40 into Oklahoma.

Due to the large increase in traffic volume on the detour highways, it was necessary for ODOT to take immediate action in the form of heavy maintenance, including overlays on portions of the detour highways, to prevent pavement failures that would endanger the traveling public (ODOT 2002). Several emergency maintenance contracts were issued to resurface highway pavements. Glover Construction Company of Muskogee was awarded contracts to resurface $12.4 \mathrm{~km}(7.7 \mathrm{mi})$ of $\mathrm{SH}-2$ beginning in Porum, $1 \mathrm{~km}(0.62 \mathrm{mi})$ of SH-100 starting in Gore, and $7.7 \mathrm{~km}$ (4.8 mi) of US-59 in LeFlore County. Tiger Industrial Transportation System, Inc., received a contract to resurface $9.5 \mathrm{~km}$ (5.9 mi) of SH-9 in Haskell County. Also, ODOT inspected 42 bridges on the detour routes and performed maintenance work, replacing bearings under the bridge decks on two bridges, located on SH-2 south of Warner and on SH-9 in the Whitefield area. 


\section{1-40 Arkansas River Bridge Detour ADT}

(Year 2001 AADT / Truck\%)

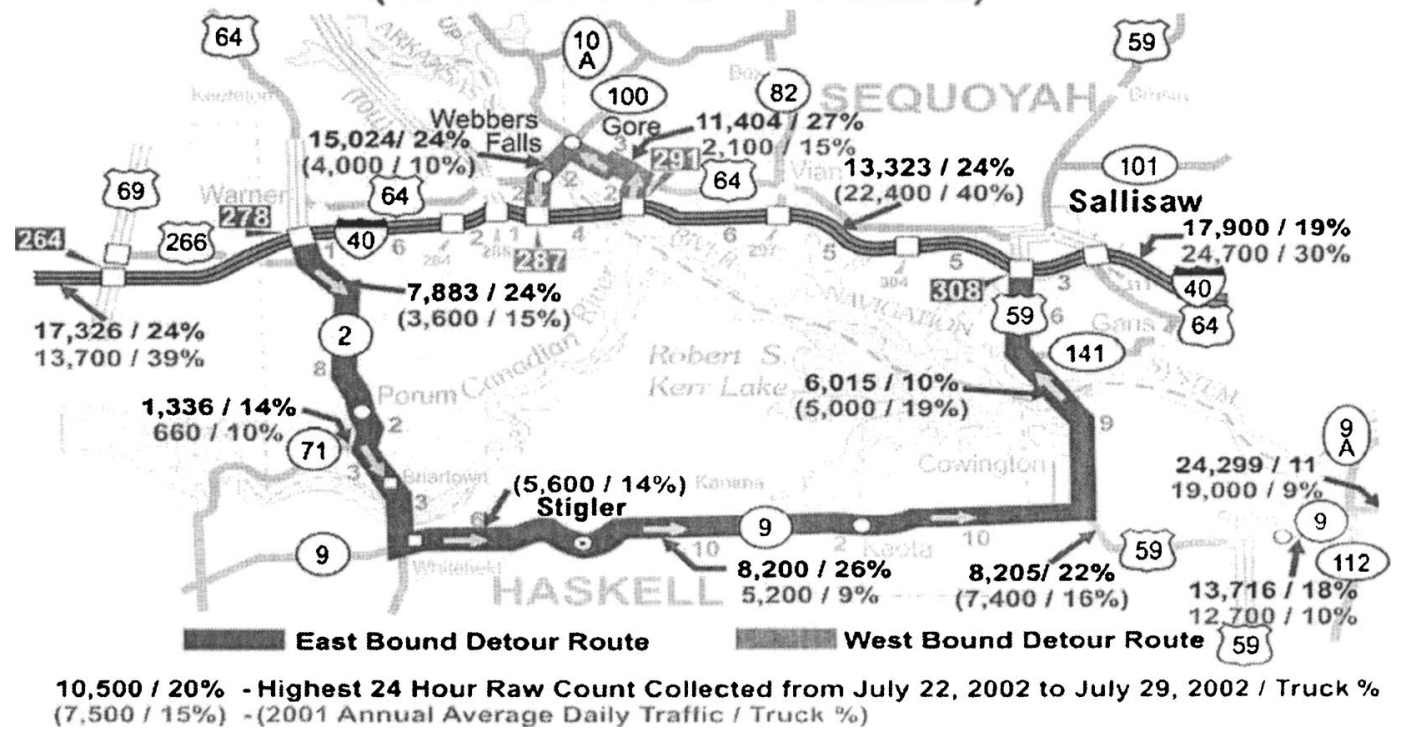

Fig. 3. I-40 detour map

\section{Recovery}

Immediately after the incident, ODOT_-working with other agencies, such as the U.S. Army Corps of Engineers, the U.S. Coast Guard, the National Transportation Safety Board, local police, the Oklahoma Army National Guard, and MeClellan-Kerr Navigational Office-engaged in rescue and recovery efforts. ODOT awarded a cost plus emergency contract to the Jensen Construction Company to remove wreckage and stabilize damaged portions of the bridge so that victims and vehicles could be recovered. Jensen Construction, headquartered in Iowa, had an office in Tulsa. At that time, the company had the necessary equipment and personnel nearby, because it was building a US-59 bridge over the Arkansas River. The recovery effort lasted 5 days. The major challenges during the recovery included: (1) coordination of first responders; (2) establishment of access and staging areas; (3) logistics of multiagency effects; (4) establishing communications; and (5) stabilization of the damaged structure.

\section{Demolition}

Demolition started as soon as the recovery effort ended. ODOT awarded a lump sum contract, a total of $\$ 850,000$, to the Jensen Construction Company for demolition work necessary to remove the damaged sections of the bridge on June 3, 2002. The duration of the contract was 16 days. Jensen would receive a $\$ 50,000$ per day bonus for each day it finished ahead of schedule and would be penalized $\$ 50,000$ per day for each day over schedule (Illia 2002). The demolition work was accomplished on time, in 16 days.

The demolition crews knocked down the remaining piers first, and then began breaking up the concrete on the spans. Spans 1 and 2 were brought down using explosives, and the debris was removed from the site. Span 3, which had completely fallen into the river, had to be removed using underwater demolition. The working environment for the underwater demolition was hazardous due to poor visibility. Demolition of the damaged section of Span 4 was the most challenging task. This span was partially damaged. One end rested on the barges, while the other end was still attached to the undamaged bridge, as shown in Fig. 2. The remainder of the bridge structure could have been further damaged if the crews had not been careful during the demolition. To prevent this from happening, the Magnolia Marine Transport Company stabilized the barges and the crews constantly monitored the movements of the bridge and barges. Combinations of demolition devices including a wrecking ball, explosives, concrete shears, and other cutting devices were used to meet the different needs at the site. The debris removed from the accident site was piled on a 2 ha $(5 \mathrm{ac})$ site on the river's west bank and was trucked or floated away during the demolition.

\section{Design for Replacement}

ODOT contacted the prequalified design consultants to prepare plans for the repair work on the day of the incident. The design contract was awarded to Poe \& Associates, Inc., of Oklahoma City on May 28, 2002. The design contract specified that the cost of the design should be no more than $\$ 137,000$ and the design firm should furnish biddable plans within 16 days (Greiner 2002). ODOT provided an incentive of $\$ 5,000$ for every day the design firm beat the 16-day schedule and a disincentive of $\$ 2,400$ for every day over 16 . Poe \& Associates started the design on May 29 and finished on June 9, four days ahead of schedule. The scope of the design included three new prestressed concrete beam spans, replacement of an existing structural steel span, three piers, and associated details. Typically, designing such structures would take 4-6 months. However, with help from ODOT and a steel detailer, Poe \& Associates accomplished the design in just 12 days, which was a tremendous time saver for the replacement project. Major reasons for the design success were that ODOT provided the original drawings immediately to the design firm and ODOT engineers were on call 24 hours per day, 7 days per week, to quickly answer any questions that the designers had. The most difficult challenges for the design firm were coordinating the design team members and keeping up with each designer's progress from day to day to ensure quality control and design checks. Each design element received at least one check, and sometimes two. Another 


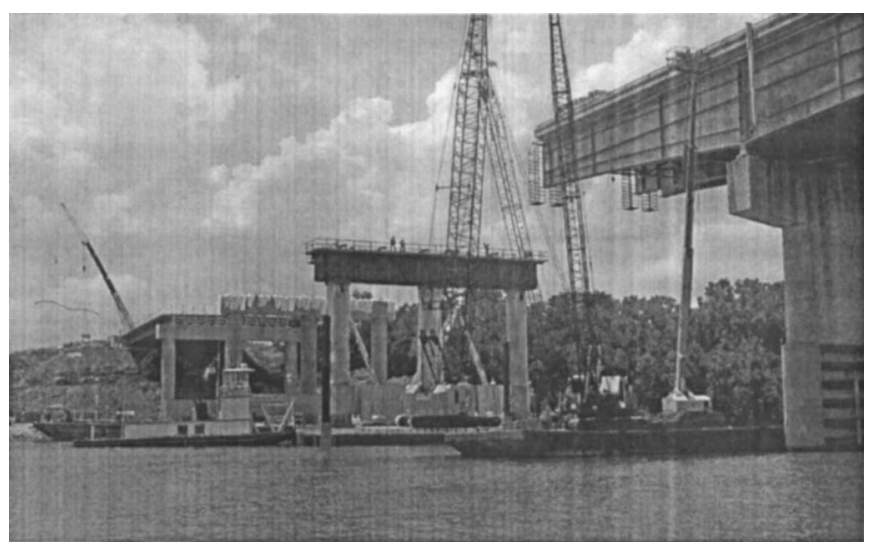

Fig. 4. New pier structures under construction

challenge was to keep designers mentally focused while working from 12 to 14 hours per day for 12 consecutive days.

The designers for the repair work made several changes on the original plans and specifications in order to expedite the replacement process. Before the incident, Spans 1, 2, and 3 were three continuous steel plate girders. After the incident, three precast, prestressed concrete girders were utilized in Spans 1, 2, and 3 in lieu of the original steel plate girders. Using concrete girders reduced the material delivery time, but increased the bridge dead load. The existing abutment could not be used due to the increased load. Also, due to the load increase, the span lengths were changed from approximately 38 to $40 \mathrm{~m}$ (125 to $130 \mathrm{ft}$ ) for Spans 1, 2, and 3. This allowed the new abutment to be built $4.6 \mathrm{~m}$ (15 ft) behind the existing abutment without removing the old abutment seat and steel piling. The original bridge was built as separate superstructures with a small gap between the directional travel lanes. This gap was eliminated in Spans 1, 2, and 3 of the new structure so that one concrete placement could be made instead of separate placements.

Span 4 was the end span of the bridge main span. The end of the span, $38 \mathrm{~m}(125 \mathrm{ft})$, was rebuilt with the same structural type steel plate girder to match the undamaged structure, but with a thicker web to eliminate transverse and longitudinal stiffeners. Before connecting the new steel girders with the existing girders in Span 4, heat straightening, a treatment procedure, was implemented to the existing girders to repair the damage. In this repair process, a limited amount of heat was applied in specific patterns to the deformed regions of damaged steel in repetitive heating and cooling cycles to produce a gradual straightening of the material [Federal Highway Administration (FHWA) 2002]. To give the contractor some flexibility, placement of the concrete deck was given an option for full width or with a construction joint at the centerline.

The old piers had two columns supporting them. The new piers were three column structures supported by drilled shafts. Pier 3 was rebuilt at the original station. Its three columns were spaced to straddle the existing spread footings that were left in place. The new piers were $2.7 \mathrm{~m}(9 \mathrm{ft}$ ) in diameter (under web wall portions), which was $0.6 \mathrm{~m}(2 \mathrm{ft})$ larger than the original. Fig. 4 shows the new pier structure under construction. The new piers were constructed with a construction joint at the top of web walls, which were full column width with some chamfering at the ends for ease of forming. Substructure concrete was permitted to be loaded at $75 \%$ of design strength.

In addition to these changes, new specifications allowed using high-early strength concrete, steel stay-in-place forms, steel diaphragms for prestressed concrete beams, and the concrete maturity method. Concrete maturity is a method for determining real-time in-place concrete strength. As soon as the concrete reached $100 \%$ design strength and had a minimum of three days curing, concrete forms were permitted to be removed and moment loadings were allowed to be applied to the structure. The concrete maturity method procedure is specified by the American Society for Testing and Materials (ASTM) C1074, Standard Practice for Estimating Concrete Strength by the Maturity Method.

\section{Bridge Reconstruction}

The bridge reconstruction contract was awarded using the "A plus B" competitive bid method (FHWA 2002). The "A plus B" method is one of the innovative project delivery methods that has been developed and implemented in the construction industry in recent years. "A" represents the cost of the project and "B" indicates the duration of the project. Using this method, the owner will evaluate the bid proposals based on not only the cost, but also the schedule. This is the ideal method for an emergency bridge reconstruction project, because time is of the essence. In the bid document, ODOT specified 72 days as the maximum time allowed to complete the reconstruction. ODOT held a prebid meeting on Saturday, June 8, 2002. The potential bidders had an opportunity to visit the site to assess the damage to the bridge and the site conditions. The contract was issued to the Gilbert Central Corporation of Fort Worth for $\$ 10.9$ million with a 57-day schedule on June 12, 2002 (FHWA 2002). The contract had a \$6,000 per hour bonus/penalty clause without cap either way. ODOT would pay Gilbert an additional $\$ 6,000$ for every hour it was ahead of the original schedule and penalize the company $\$ 6,000$ for every hour it was behind the schedule. The reconstruction started at 6:00 pm on June 12, 2002, with two 12-hour shifts per day, 24 hours per day, 7 days per week. On average, there were 70-80 workers on the site. The project finished at 10:00 am on July 29, 2002, for a total time of 46 days and 16 hours, the fastest completion of a project of its type in U.S. history. Reconstruction was ahead of the original schedule by 10 days, 8 hours, and Gilbert received a $\$ 1,488,000$ bonus. ODOT also benefited from the early completion of the project, because traffic engineers estimated that the total user cost was $\$ 430,000$ per day for every day that the bridge was not open. Under normal conditions, it would have taken at least six months to finish the reconstruction.

The major scope of repair work involved constructing a $160 \mathrm{~m}$ (524 ft) long combination concrete and steel girder that would tie into the undamaged four-lane bridge structure, three piers, four spans, an abutment, a $9 \mathrm{~m}$ (30 ft) long concrete approach slab,

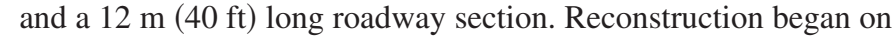
the west side of the bridge and moved toward the still-standing roadway in the center. Both ODOT and Gilbert committed the necessary resources and furnished experienced supervisors and crews to ensure that the project would be constructed as fast as possible. ODOT created a special construction residency. The assistant bridge engineer for design was on call 24 hours per day, 7 days per week. A 13-member team of inspectors was formed to oversee the reconstruction of the bridge. Some of the inspectors were retired ODOT employees. The average experience for the 13 bridge inspectors was 20 years. Inspectors were also sent to the steel fabrication shops to make sure that the steel plate girder beams were fabricated as designed and satisfied all the standards. Under normal circumstances, ODOT probably would have only two inspectors assigned to such a project. 
Gilbert Central Corporation, a subsidiary of Peter Kiewit Sons, Inc., had built two bridges in Tulsa and was the contractor on major repairs to Oklahoma City's cross-town expressway. The company was also working on a large bridge at Dallas-Fort Worth Airport and an $\$ 800$ million bridge in the San Francisco Bay area. To meet the challenge of the I-40 bridge, Gilbert deployed multiple crews working concurrently, employed a full time on-site scheduler to prepare daily critical path method (CPM) schedule and resource requirements, and mobilized backup equipment. The company had experienced decision makers on site to quickly respond to any issues or questions during the reconstruction. To make sure that safety would not be compromised during the repair project, Gilbert offered a $\$ 2,000$ safety bonus to each crew member if they had no accidents at the end of the project.

One of the major challenges during the reconstruction was the delivery of steel plate girders. Immediately after the incident, ODOT decided to replace much of the damaged steel girders with precast, prestressed concrete girders, with the exception of Span 4, which was tied into the existing bridge, because ODOT anticipated that steel suppliers could not meet the aggressive reconstruction schedule. Span 4 required 210 tons $(190,680 \mathrm{~kg})$ of steel including four replacement girders, 12 cross frames, four lines of stringer beams, and lateral bracing (Melnick 2002). Delivery of the structural steel was a critical activity on the CPM schedule. The National Steel Bridge Alliance (NSBA) and several steel fabricators assured ODOT that steel delivery could meet the ambitious schedule. On June 2, 2002, Tensor Engineering sent its premier bridge detailer to the steel design firm White \& Associates, of Oklahoma City, to work on the design drawings. The designers utilized heavier webs to eliminate the need for most of the stiffeners, which ultimately sped up the fabrication process. All design drawings were sent via e-mail to speed the process. Tensor Engineering sent the mill orders to the fabricator, Trinity Industries, Inc., on June 12, 2002. Detailed shop drawings were completed over the next five days and approved by ODOT in the shop on the day they were submitted.

One of the challenges during the design of shop drawings was how to match the existing field splice. The fabricator requested the last $1.5 \mathrm{~m}(5 \mathrm{ft})$ of the existing damaged girders on Span 4 and used the splice plates to match-draw new splice plates. New splice plates were bolted into position on the new girders in the shop and were then connected to the existing girders in the field (Melnick 2002). Bethlehem Steel Company received the order to provide the needed steel materials on June 19, 2002, and started to ship the materials on June 24, 2002. The company was willing to disrupt its regular production schedule to meet the required delivery schedule. The delivery of steel girders was completed six days ahead of schedule due to the hard-working people in the steel industry and the bonuses provided by Gilbert.

In addition to efforts from the construction industry, coordination among federal, state, and tribal governments was crucial to putting the bridge back into commission on the fast track. As the sole owner of the Arkansas Riverbed and banks at Webbers Falls, the Cherokee Nation controls the land around the reconstruction site. From day one, the Cherokee Nation contributed land and manpower and facilitated the project by making work areas easily accessible to the general contractor and subcontractors ("Cherokee Nation" 2002). The Federal Highway Administration (FHWA) approved \$3 million in federal emergency relief funds to get the repair work started immediately (FHWA 2002). Through the repair process, FHWA provided technical expertise and assistance to ODOT, particularly in the areas of bidding and contract administration. Both agencies worked together to

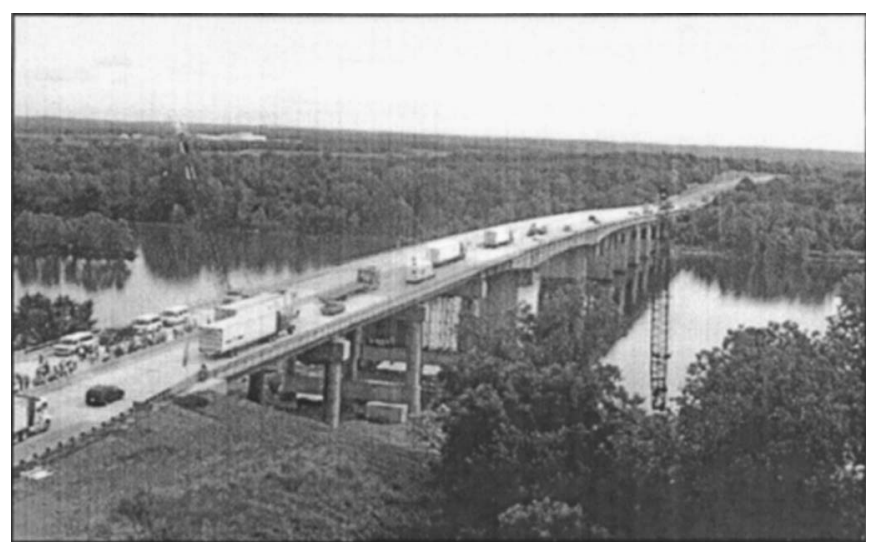

Fig. 5. I-40 bridge reopened to traveling public

streamline the bid review and approval procedures and get the reconstruction contract ready to put out for bid. ODOT also received technical help and cooperation from the U.S. Army Corps of Engineers, the U.S. Coast Guard, and other state DOTs. Fig. 5 shows the bridge as it was reopened to the traveling public on July 29, 2002.

\section{Lessons Learned}

There were many factors contributing to the success of the response to the I-40 tragedy. In order to document what can be learned from this extreme event, the research team conducted this case study. During the study, the research team reviewed literature including information posted on Web sites, interviewed people who were involved in the repair of the bridge via telephone, and performed surveys. Notwithstanding its terrible consequences, the I-40 Webbers Falls Bridge tragedy provides useful lessons for government agencies, engineering and construction firms, and material suppliers that must plan for enhanced responses in case of future incidents. The following summary lists lessons learned from this extreme event:

1. A quick response to the incident was the key to mitigate the losses and ease the inconvenience to the traveling public. Response actions included, but were not limited to, stabilizing the damaged structure immediately to prevent further damage to property and injury to traveling public, providing the required construction equipment and manpower for rescue and recovery efforts, establishing detour routes, and making the detour information available to the general public as quickly as possible to ease traffic congestion.

2. Using established contracting methods and procedures sped up the contract negotiation process and avoided future contract disputes. During the replacement process, ODOT utilized both traditional contracting methods, such as costplus, time and materials, and lump sum, and innovative contracting methods such as "A plus B." All of these delivered positive results.

3. Huge incentive and disincentive clauses in the contracts played a very critical role in motivating design firms, contractors, and material suppliers to finish their work on or ahead of time. In particular, using the "A plus B" contracting method and offering a huge incentive in the reconstruction reduced its duration from 72 days to 46 days, 16 hours.

4. The duration of design for the new structure was shortened 
because the original design drawings and specifications were provided quickly to the design firms and ODOT engineers were on call 24 hours per day, 7 days per week, to answer any design-related questions.

5. Commitment of the necessary resources such as manpower from all parties, which included ODOT, design firms, contractors, and material suppliers, accelerated the replacement project. During the replacement process, all parties worked overtime. Contractors rebuilt the bridge with two shifts working around the clock.

6. The spirit of cooperation among the parties involved in the replacement project was very high. People worked together as partners. This partnership atmosphere built trust, improved communications, reduced conflicts, and overcame the bureaucracies and other adversities during the replacement process. Suggestions and ideas on how performance could be improved were discussed daily.

7. Getting strong support from the community allowed the execution of the replacement project to run effectively and smoothly. The Cherokee Nation, who controlled the land around the site, contributed land and manpower and facilitated the project by making work areas easily accessible to contractors.

8. Changing the normal DOT operational procedures expedited the reconstruction. For example, ODOT approved the shop drawings the day they were submitted. Under normal conditions, it would take weeks to get approval. Also, ODOT inspectors were sent to the steel plant and fabrication shop to conduct quality inspection, because the fabrication of the steel girders was the critical activity in the schedule.

9. The maturity method was used successfully to expedite the concrete construction process. Time-based specifications for concrete were modified to implement the maturity method.

Although the replacement project was finished more than 10 days ahead of the original schedule with a good quality and safety record, there are areas for state DOTs to consider for future improvements. These potential improvements may be summarized as follows:

1. The duration of the emergency bridge replacement project needs to be estimated more accurately. Nobody predicted that the replacement of I-40 bridge would be ahead of schedule by 10 days and 8 hours until the very end of the project. An accurate estimation of schedule will improve communication between state DOTs and the traveling public. To achieve this requires state DOTs to collect real project data and conduct schedule analysis.

2. State DOTs should continue to search for new construction technology that could expedite and improve the construction process. Areas such as underwater demolition and coordination among the parties involved in the replacement process show great potential.

3. To expedite the replacement project, both ODOT and private firms pulled some of their resources (such as manpower and equipment) from existing design and construction projects. This action had negative impacts on existing projects. State DOTs need to address resource issues in their emergency response plans. One of the possible solutions is to utilize retired employees.

\section{Discussion and Conclusion}

In addition to the lessons learned, the bridge replacement process was identified through this detailed case study. A general model

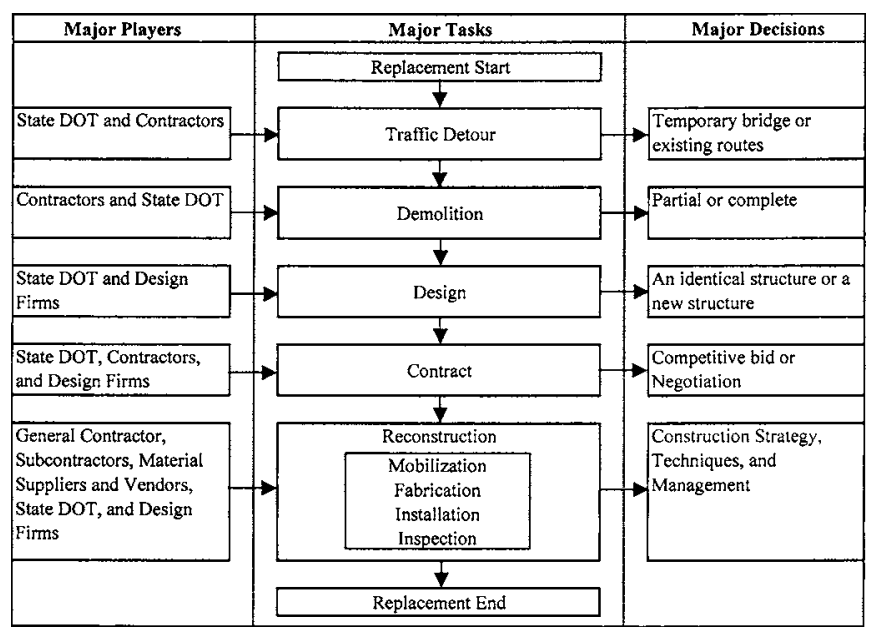

Fig. 6. General model for bridge replacement

was developed to represent the process, as shown in Fig. 6. This model includes three key elements: (1) major players; (2) major tasks; and (3) major decisions. Major players are parties such as bridge owners, state DOTs, design firms, contractors, material suppliers, and vendors, who have the responsibility to conduct the bridge replacement tasks and make major decisions during the bridge replacement process. Major tasks of bridge replacement include traffic detour, demolition, design, contracting, and reconstruction. At each stage, major decisions need to be made, which have significant impacts on the outcomes of bridge replacement. For example, during the design stage, the most important decision is to decide whether the bridge shall be rebuilt using an identical structure or a new structure. If the decision is to use an identical structure, then the design work is simple if the original drawings and specifications are archived. In some cases, using an identical structure may not be the best way to replace a bridge quickly. This was the case for the I-40 Webbers Falls Bridge. The original structure was a continuous haunched steel girder bridge. After the incident, precast, prestressed concrete girders were utilized in Spans 1, 2, and 3 in lieu of the original steel girders to reduce the material delivery time.

One question that must be considered is: Under what conditions/justifications shall decision makers/bridge designers replace the damaged bridge using a different structure instead of an identical structure? Making such a decision is difficult, and people who are capable of making the judgment must have considerable experience in the field. However, these people are not always available, nor do they always have the time to consult all possible references and review available data.

Bridge replacement is a complicated operation that involves many parties. It requires each party to make technical and management decisions at different stages in a very short period of time. Traditionally, each party makes decisions that best suit his or her interests, decisions which are known as "local optimal." However, local optimal may not lead to the best solution for the overall replacement project, known as the "global optimal." The major challenges of achieving "global optimal" for bridge replacement are communication and coordination among parties involved in the replacement process. Currently, there is no system that coordinates the different parties' tasks through gathering, processing, manipulating, storing, and distributing required information/data during the replacement process for decisionmaking purposes. Poor communication and coordination could 
result in cost overruns and inaccurate construction schedule forecasts. For example, nobody predicted that the replacement of the I- 40 bridge would be ahead of schedule by 10 days, 8 hours, until the very end of the project.

For these reasons, the conclusion is reached that there is an urgent need to develop a knowledge-based information system for bridge replacement that integrates all parties' tasks during the bridge replacement process. The developed system will help the major players of bridge replacement to select optimal methods for traffic detour, demolition, bridge replacement design, contracting, and reconstruction. If successful, the system not only will improve the communication and coordination among parties, but will also speed up the bridge replacement process and minimize impacts to the traveling public after extreme events.

\section{Acknowledgments}

The writers would like to thank Mr. Gregory Allen, Mr. George Raymond, and Mr. Bob Rusch of ODOT, Mr. Jim Poe of Gilbert Central Construction, Inc., and Mr. Tim Purkeypile of Poe \& Associates for their vital input and cooperation during the case study. A special thanks goes to the state DOTs who provided financial support and guidelines for this research project. These DOTs are Georgia, Illinois, Minnesota, Mississippi, New Jersey, New Mexico, Ohio, South Carolina, and Texas.

\section{References}

"Cherokee Nation, ODOT pledge cooperation on I-40 bridge." (2002). Cherokee Nation News Release, 〈http://www.cherokee.org/ NewsArchives/News2002Page.asp?ID=532〉 (Apr. 30, 2003).

Federal Highway Administration (FHWA). (2002). "Accelerated bridge repairs: Meeting the challenge in Oklahoma." FOCUS, 〈http:// www.tfhrc.gov/focus/aug02/01.htm $\rangle$ (Mar. 22, 2003).

Greiner, J. (2002). "Work begins on damaged I-40 bridge." NewsOK.com, 〈http://www.newsok.com/cgi-bin/show_article?ID=870300\&pic $=$ none $\& \mathrm{TP}=$ getcc $\rangle($ Mar. 26, 2003).

Illia, T. (2002). "Oklahoma to rebuild barge-battered I-40 bridge." ENR, 〈http://www.construction.com/NewsCenter/Headlines/ENR/ 20020617a.asp (Mar. 22, 2003).

Melnick, S. L. (2002). "Steel speeds recovery." Modern Steel Constr., September, 51-55.

(ODOT). (2002). "I-40 bridge update: Day 29 of 57 construction days." Public Information, Oklahoma Department of Transportation 〈http:// www.okladot.state.ok.us/public-info/i40bridge-press/ july_10_Update.htm> (Mar. 26, 2003).

"Oklahoma speeds to replace span following barge collision." ENR, 〈http://www.construction.com/NewsCenter/Headlines/ENR/ 20020603a.asp (Mar. 22, 2003).

Stidger, R. W. (2002). "Downed I-40 bridge opened in just 47 days." Better Roads, 〈http://www.betterroads.com/articles/nov02c.htm〉 (Mar. 22, 2003). 